\title{
An Empirical Research on Investor Biases in Financial Decision-Making, Financial Risk Tolerance and Financial Personality
}

\author{
Bilgehan Kübilay ${ }^{1} \&$ Ali Bayrakdaroğlu ${ }^{2}$ \\ ${ }^{1}$ Graduate School of Social Sciences Institute, Mugla Sitk1 Kocman University, Mugla, Turkey \\ ${ }^{2}$ Business Administration Depertmant, Mugla Sitkı Kocman University, Mugla, Turkey \\ Correspondence: Ali Bayrakdaroğlu, Business Administration Depertmant, Mugla Sitkı Kocman University, Mugla, \\ Zip Code: 4800, Turkey. Tel: 90-252-211-1363.
}

Received: March 17, 2016

Accepted: March 29, 2016

Online Published: April 6, 2016

doi:10.5430/ijfr.v7n2p171

URL: http://dx.doi.org/10.5430/ijfr.v7n2p171

\begin{abstract}
In financial investment decisions to be made by individual investors, it is highly important that they should be aware of the possibility of facing with psychological biases by knowing their own personality traits and should consider their own financial risk tolerances. In this study, the relation between personal traits, psychological biases and financial risk tolerance of inverstors were tested through a questionnaire. Sample of the study were selected among individual inverstor who live in İstanbul and operate in financial markets. The hypotheses made within the scope of the study were tested by chi-square analysis and logistic regression analysis. As a result of the hypotheses testing, it was concluded that there was a significant relation between the personality traits of investors and the psychological biases they faced and that the personality traits of investors affected their financial risk tolerances.
\end{abstract}

Keywords: behavioral finance, financial decision making, psychological biases, investment risk tolerance, financial personality

\section{Introduction}

In the financial literature, there are many great conventional theories (e.g. Efficient Market Hypothesis (Fama 1970), Modern Portfolio Theory (Markowitz 1952), Capital Asset Pricing Model (Jenson, Scholes, and Black 1972) regarding the market trends and the behavior of individuals in their investment options and a great number of studies support those theories. In this sense, conventional financial theories assume the individual investors as rational beings who subject many data to numerical analysis after obtaining them and aim at maximizing the benefit that they hope to receive.

Recent studies made in the field of finance show that although individual investors want to maximize their options rationally in their investment decisions, to vary their portfolios and to avoid risk, they fail to fulfill those in their investments. Thus, human behavior don't depend always ona a logical base stipulated by conventional financial theories and may move away from rational behaviors in time (Kahneman and Tversky 1979). It is known that there are many great factors limiting, and directing individual investors who invest in financial markets and restraining them from behaving rationally (Camerer 1995; Loewenstein 1999).

One of the most important factors affecting the financial decisions made by investors is the psychological biases (Camerer 1997; Bailey 2012; Breuer, Riesener, and Salzmann 2014). The psychological biases make the investment decisions of individuals into irrational decisions and, instead, couse individuals to make intuition and feeling based decisions. Unlike the conventional finance, the approach, which assumes that inverstors are irrational is known as behavioral finance. Behavioral finance suggests this assumption by discussing the psychological biases affecting the financial investment decisions of investor (Jureviciene and Jermakova 2012). In fact, this assumption has a characteristic fulfilling the classical and neoclassical finance theories prevailing in the financial analysis. From this point of view, lots of reactions against conventional theory are clarified by synthesizing the psychology and finance (Parker 2014; Siddiqui and Singh 2009). In recent times, economic models, which take those into consideration in order to make better decisions bye inverstors by establishing control over the psychological biases, take place in the literature (Bruni and Sugden 2007). 
In the literature, it is discussed that the personality traits of investors and the risk tolerances of those personality traits as well as their psychological biases affect the financial decisions (Durand, Newby, and Sanghani 2006; Murgea 2010; Thomas and Rajendran 2012; Venter, Michayluk, and Davey 2007). In many cases, investors are not aware of their wrong behaviors. If investors are aware of their psychological biases by knowing their own personality, they can make their financial decisions in a more conscious way. Thus, this way of thinking reduces their perception failures and increases the quality of their decisions. If an investor knows himself better, so he can gain more or he can maintain his wealth (Zweig 2011).

It was examined that whether investors show psychological biases or not, the psychological biases that they show, the effects of psychological biases on financial decisions and the effects of psychological biases on risk have generally been examined (Kojabad 2012). Bashir et al. (2013a) determined that neurotic people show more herd behavior bias than people who are and who have well-adjusted and clear personality traits. Lakshmi et al. (2013) have asserted that behavioral biases such as herd behavior, overconfidence, risk aversion, cognitive dissonance, representativeness heuristic and reflection effect vary in investors who make short-term and long-term investment.

Ali and Waheed (2013) have searched the effects of personality traits, behavioral biases, perceived personal control and cultural factors on the risk attitudes of individual investors. Kowert and Hermann (2013) point out that the prospect theory fails to estimate the behaviors of individuals. and there is a strong relationship between personality traits and risk-taking.

Bashir et al. (2013b) have put forth that as extraversion increases for workers in business life, the confidence level decreases. The findings of the study carried out Jamshidinavid, Chavoshani, and Amiri (2012) have show that extrovert investors are in overconfidence bias. Zaidi and Tauni (2012) determined a positive relationship between overconfidence and personality trait such as agreeableness, extraversion and conscientiousness.

Jureviciene and Jermakova (2012) express that although a great majority of subjects have high educational level, they avoid financial difficulties, take medium risks and prefer more reliable investment instruments.

Lin (2011) points out that many investors have strong investment biases such as overconfidence, disposition effect. He argues that the crisis arose in 1990s caused by herd behavior is the evidence of this. Sadi et al. (2011) argue that one of the most significant factors on financial decisions of investors is perception failures. Durand, Newby, and Sanghani (2006) claim that neurotic and open-minded people take high risks, those people and people who take high risks buy and sell more. Brozynski, Menkhoff, and Schmidt (2004) express that herd behavior, risk-taking and overconfidence are diminished by experience.

However, there are few studies in the literature concerning the classification of personalities of investors and the behavioral bias tendencies shown by personality traits. In this scope, the motivation of study is based on determining the relationship between personality traits and psychological biases of individual investors and their financial risk perceptions.

This study consists of five sections. In the following second section, psychological biases argued by behavioral finance, investor risk tolerance and financial personality concepts were discussed briefly. In the following section, there is an analysis on investor biases with regard to investment psychology, financial risk tolerance and financial personality by considering individual investors. The last section of the research was concluded with evaluations, opinions and suggestions regarding the hypotheses.

\section{Theoretical Framework}

\subsection{Psychological Biases}

A successful investment depends on the determination of psychological biases as well as financial knowledge on the lowering of those biases (Jureviciene and Jermakova 2012; Sahi, Arora, and Dhameja 2013). It is unlikely that people decide without any bias. However, the determination of those biases and investment rules can enable the reduction of the biases (Parker 2014; Ramiah et al 2014). Kahneman and Tversky (1979) state that individuals frequently make mistakes in analyzing the situations including probability and economic analysis. In this sense, the most known biases in the literature were summarized below.

Representativeness heuristic shows that individuals correlate between probabilities and similarities by causing basic information to be ignored (Lagnado and Sloman 2004). Representativeness bias is related to evaluations made by individuals mostly depending on the similarity of a case with another case (Goldstein 2013). 
Availability is a judgmental heuristic (Murgea 2010). This bias is related to the realization frequency of cases. Thus, it means that individuals attribute the realization frequency of a case to the occurrence rate of that case, to available and evocable examples or cases (Laibson and Zeckhauser 1998).

Anchoring Heuristic showed up in an environment where there was an increase in the access to information opportunity of individuals. It is quite difficult to decide in an environment where there is so much information for human brain (Lehrer 2009). The reason why people anchor arises from uncertainty and lack of knowledge or aversion. Thus, they try to avoid uncertainty. If people have insufficient data, they pay attention to that when they face with the first data to reduce uncertainty; because this will reduce uncertainty and relieve the mind of individual (Tacer 2007).

Overconfidence is unreasonable belief of an individual in his mind, intuitions and decisions. This stems from the fact that individuals think themselves more intelligent than they are or think that they have better knowledge (Siddiqui and Singh 2009). Dobelli (2014) defines this situation as the measure of the difference between real knowledge of people and the knowledge which they think that they know.

Overoptimism is related to overconfidence. However, it includes different psychological biases (Dowling and Lucey 2010). Optimism is to think that the results of actions will be positive. Over optimism follows overconfidence and is the belief that events to occur in the future will be really better (Dowling and Lucey 2010).

Regret Aversion is seen as over-focusing on regret felt when a bad decision is made. Trouble felt due to mistake made is disproportionate to the dimension and nature of mistake. Fear of regret plays an important role in investment decisions. Even this causes financial decisions to be delayed. Regret aversion in stock trading shows itself as keeping stocks which are lost during a long time even if there is no expectation (Eaton 2000).

Herd Effect is the fact that a group of investors trade in the same direction for a time. In the herd effect, individuals who are ignorant, illiterate and emotional are mentioned in the same category (Nofsinger and Sias 1999). It is known that the personalities of individuals affect their tendencies of showing herd behavior (Lin 2012). Investors tending to show herd behavior generally have low self-confidence. They consider the signals in the market and benefit from the decisions of professional investors in order to increase professional competences in their investment decisions (Lin 2011).

\subsection{Outlook on Risk in Terms of Behavioral Finance and Financial Personality}

It is known that risk is a factor forming the financial decisions of individual investors. Financial risk tolerance is the willingness of individuals to agree to make financial decision in case of maximum uncertainty (Prabhakaran and Karthika 2011). In other words, risk tolerance is a complex psychological fact that reflects the attitude of individual against risk (Hallahan, Faff, and McKenzie 2004).

According to Roszkowski and Davey (2010), risk tolerance has both a constant and a variable characteristic. It either remains the same like the blood group of a person or changes like the mood of a person. Therefore, it may be vain to ground an investment plan according to this trait. While people having high risk tolerance accept variable, inconstant events, those who have low risk tolerance prefer certainty (Grable and Lytton 1998). It is not sufficient to know only the risk tolerance of an individual; individual has also other measuring aspects such as his/her tendency of bearing of risk (McGuckian 2013).

Another factor which is as effective as risk tolerance in financial decision-making is personality trait which investor has. The personality is the total of traits which distinguish an individual from other people and that an individual has by nature and gains later in his life. All traits such as emotions, abilities, motives, nature, social, physical-psychomotor and cognitive traits, personality and values, beliefs, attitudes, opinions of people are a concept including all aspects of human behaviors and form the personality (Kleinman 2014).

Personal and individual vulnerability against behavioral biases, risk attitude and time preference play an important role for the development of investment strategies. In the researches made by Lin, H.W. (2011), Jamshidinavid, Chavoshani and Amiri (2012), Jureviciene and Jermakova (2012), Brozynski, Menkhoff and Schmidt (2004) and Kowert Hermann (2013), it is seen that there is a strong relationship between personality and biases in financial decision-making.

Considering the results obtained from tests made in order to evaluate the financial personality of the investor, the financial personality of individual and accordingly the investment portfolio desired to be created can be understood (Bailard, Biehl, and Kaiser 1986; Pompian 2008). Thus, this will minimize the misperception and misjudgment for 
the advices that investment specialists who are financial consultants will give only considering the psychological biases of investors (McGuckian 2013).

It is impossible to examine different investor traits within a unique systematical frame, to develop an ideal investor profile without scientific research. The reason is that the markets have different traits and the personality traits required for investment success vary from person to person. Moreover, the success of different people in different markets and at different times can be listed among the reasons. For this purpose, the trait researches are needed for determining common traits of all investors, showing those traits if any. The researches made in this field show that the personality can be divided into five main traits (Peterson, 2012). One of these traits is five-factor personality model.

Five-factor personality model is one of the most common and the most effective models in trait researches (McCrae 2009). These five factors have been known as Big Five since Goldberg (1971). Big Five Factors were determined as Openness to Experience, Conscientiousness, Extraversion, Agreeableness and Neuroticism or Emotional Stability (Borghans et al. 2008). This model reflects considerations regarding the world and their interaction with world according to their personality traits by showing the behavioral tendencies of individuals.

\section{Research Method}

\subsection{Sample, Method, Hypotheses and Model}

Universe of research consists of individual investors trading in financial markets. The research sample consists of individual investors residing in Istanbul and trading in financial markets. Investors must actively transact in order that the research can achieve its aim. The research is limited to Istanbul city as it is a financial center and financial investors can be reached there easily. Thus, individual investors trading in financial markets in Istanbul were included in survey.

Before collecting actual data from target population, pilot testing of questionnaire was employed. The sample selected for pilot testing was having similar personality traits as target population. For this purpose 40 investors from Istanbul were conducted randomly.

The survey method was used as data collection method in this research. The survey forms started to be applied in November 2014 and were completed April 2015. The survey forms were distributed to 1.800 people and 536 of them have responded. Questionnaire used in the reseach consists of 81 questions and includes sections of three scales. These are psychological biases scale, five-factor personality scale and financial risk tolerance scale. For data analysis, SPSS (Statistical Package for Social Sciences) for Windows 22 was employed.

All scales used in the research were tested by Cronbach's alpha reliability analysis. Chi-square analysis and logistic regression analysis were used in the research. The relationship between personality traits and psychological biases was tested by chi-square analysis and the relationship between personality traits and financial risk tolerance was tested by logistic regression analysis.

Hypotheses of the research were divided into two main hypotheses as Hypothesis A and Hypothesis B. Hypotheses are given below:

HA: There is a relationship between personality traits and psychological biases of investors.

HB: There is a relationship between personality traits and financial risk tolerances of investors.

The model to be used in the research was designed within the scope of these hypotheses. Accordingly, Figure 1 shows the research model. 


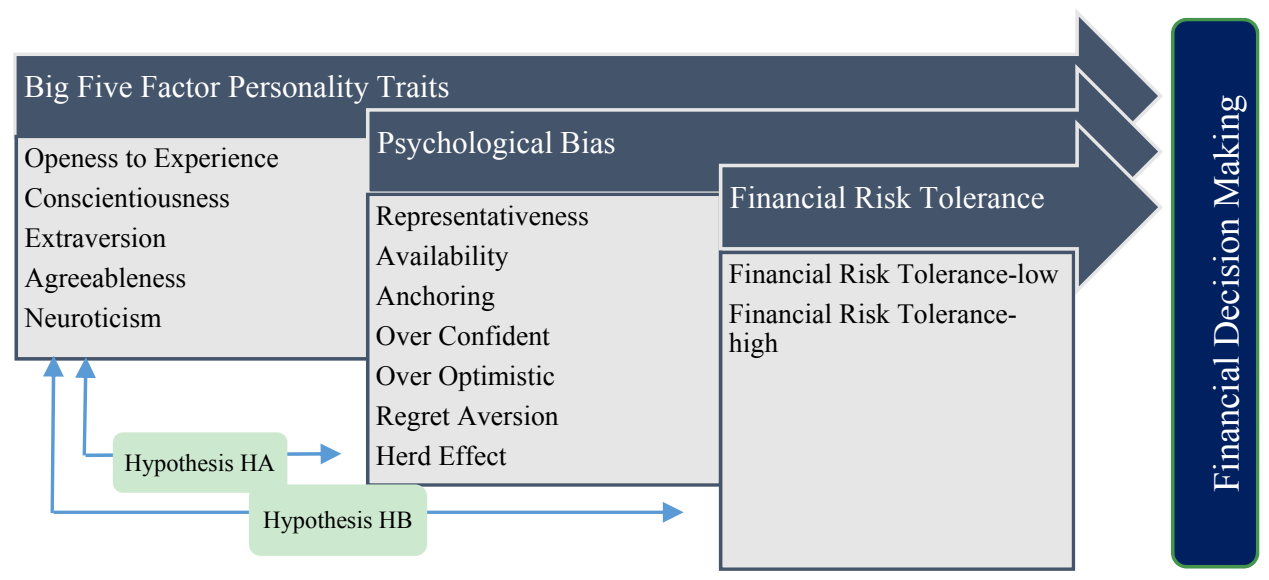

Figure 1. Research Model

Firstly, the relationship between personality traits and psychological biases was depicted in the model. And then the relationship between personality traits and financial risk tolerances was searched in order to test whether the fact that individuals have high or low financial risk tolerances can be explained by their personality traits or not.

\subsection{Scales Used in the Research}

Three scales which are psychological biases scale, five-factor personality scale and financial risk tolerance scale were used in the research. The psychological biases scale used for determining psychological biases was created by the studies made by the leading researchers (i.e. Sutherland, 2011; Pompian, 2006) of behavioral finance. The psychological biases scale consists of 24 questions so as to determine 7 psychological biases.

The five-factor personality scale enables to examine systematically the relationships between personality traits and behaviors. The five-factor personality scale used in the research was developed by John, Donahue and Kentle (1991). There are 44 questions and 5 dimensions in this scale, the validity and reliability of which are tested.

The financial risk tolerance scale used in the study was developed by Grable and Lytton (1999). Different scores were given according to the answers given to the questions of financial risk tolerance. Each answer was weighted (1 to 4) by its risk rate. The financial risk tolerance scores were obtained in accordance with the answers of participants. While the financial risk score of people who are willing to take risk was kept high, the risk score of those who are risk averse was kept low.

Cronbach's Alpha (Note 1) model was taken into consideration in the reliability analysis made. The scale is accepted as reliable when Cronbach's Alpha value is 0,70 or above (Nunnally and Bernstein 1994). The reliability analysis results of psychological biases scale, personality scale and financial risk tolerance scale were given in Table 1.

Table 1. Reliability analysis results of scales

\begin{tabular}{lcc}
\hline Scale & Cronbach's Alpha & Number of question \\
\hline Psychological Biases & 0,705 & 24 \\
Grand mean: 1,81 & \\
The suitability of the model: Friedman's Chi-Square: 5081,977 & \\
Sig: ,000 & 0,800 & \\
Five-Factor Personality Traits & \\
Grand mean: 3,50 & \\
The suitability of the model: Friedman's Chi-Square: 5086,366 & 0,726 \\
Sig: ,000 & \\
Financial Risk Tolerance & \\
Grand mean: 2,02 & \\
The suitability of the model: Friedman's Chi-Square: 2047,348 & \\
Sig: ,000 & & \\
\hline
\end{tabular}

Notes: We use Anova Friedman's Chi-Square to compute the Reliability Test. Alpha model was applied. 
In the reliability test made, it is seen that the reliability values of mentioned scales are sufficient.

\section{Results}

\subsection{Descriptive Statistics of Investors}

\subsubsection{Assessment of Demographic Traits of Investors}

Descriptive statistics related to demographic traits of investors included in the research were shown in Table 2.

Table 2. Descriptive statistics related to demographic traits of investors

\begin{tabular}{cccccc}
\hline Sex & (f) & $(\%)$ & Marital Status & (f) & $(\%)$ \\
\hline Male & 477 & $\underline{89}$ & Married & 257 & 47,9 \\
Female & 59 & 11 & Single & 279 & $\underline{\mathbf{5 2 , 1}}$ \\
\hline Age Groups & $(\mathrm{f})$ & $(\%)$ & Educational Status & $(\mathrm{f})$ & $\mathbf{( \% )}$ \\
\hline $18-20$ & 20 & 3,7 & Graduate & 136 & 25,4 \\
$21-30$ & 217 & $\underline{40,5}$ & Universty & 343 & $\underline{64,0}$ \\
$31-40$ & 158 & 29,5 & High School & 51 & 9,5 \\
$41-50$ & 94 & 17,5 & Secondary School & 5 &, 9 \\
51 and above & 47 & 8,8 & Primary School & 1 &, 2 \\
\hline
\end{tabular}

Notes: (f) shows the number of the respondents. (\%) shows the percent of the respondents.

As seen in Table 2, in terms of the distribution by sex, $89 \%$ of 536 investors are males and $11 \%$ of them are females. Thus, within the scope on the study, it was reached that males predominantly transact in financial markets. This can be caused by the fact that male investors are more interested in financial markets or males are predominantly in labor market. Considering the distribution of age groups of investors, it is seen that investors between 21-30 age range are in majority by $40,5 \%$. Within the scope of the study, it can be said that the majority of investors transacting in financial markets are young and have working age.

When the distribution by marital status of investor is examined, it is seen that singles are in majority by $52.1 \%$. However, there is no big difference with married investors. In the research, the fact that $64 \%$ of investors have bachelor's degree and $25,4 \%$ of whom have master's degree shows that the educational level is high. It can be said that there should be a certain educational level for transacting in financial markets, so people having a certain educational level are interested in financial markets.

\subsubsection{Assessments of Investors Traits Concerning Personality, Biases and Risk}

Descriptive statistics concerning the psychological biases, personality traits and financial risk tolerances of investors included in the research are shown in Table 3.

Table 3. Descriptive statistics concerning the investor traits of personality, bias and risk tolerance

\begin{tabular}{|c|c|c|c|c|c|}
\hline Personality Traits * & (f) & $(\%)$ & Psychological Biases * & (f) & $(\%)$ \\
\hline Extraversion & 470 & 87,7 & Representativeness & 434 & $\underline{81,0}$ \\
\hline Agreeableness & 525 & $\underline{97,9}$ & Availability & 351 & 65,5 \\
\hline Conscientiousness & 518 & $\underline{96,6}$ & Anchoring & 215 & 40,1 \\
\hline Neuroticism & 331 & 61,8 & Overconfidence & 377 & 70,3 \\
\hline Openess to Experience & 520 & $\underline{97,0}$ & Overoptimistic & 226 & 42,2 \\
\hline Financial Risk Tolerance & (f) & $(\%)$ & Regret Aversion & 301 & 56,2 \\
\hline High & 233 & 43,5 & Herd Effect & 283 & 52,8 \\
\hline Low & 303 & $\underline{56,5}$ & & & \\
\hline
\end{tabular}

Notes: *Survey respondents gave more than one answer to personality traits and psychological biases. (f) shows the number of the respondents. (\%) shows the percent of the respondents. 
As seen in Table 3, about $98 \%$ of investors included in the research mostly have agreeable personality traits. This is followed by the investors having open to experience personality trait by $97 \%$ and by those who have conscientious personality trait by about $97 \%$. Additionally, while about $88 \%$ of investors have extravert personality trait, $62 \%$ of them have neurotic personality trait.

On the other hand, considering the psychological biases of investors, it is seen that $81 \%$ of 536 investors have Representativeness Heuristic, about $70 \%$ of them have Overconfidence, about $65 \%$ of them have Availability Heuristic, about $56 \%$ of them have Regret Aversion, about 53\% of them have Herd Behavior, about $42 \%$ of them Over Optimism and about $40 \%$ of them have Anchoring Heuristic.

Accordingly, when examining whether financial risk tolerances of investors included in the research are high or low, it is seen that $56,5 \%$ of the inverstors have low tolerance, $43,5 \%$ of them have high tolerance. In other words, it was determined that there was no big difference between them and investors were not very willing to take risk.

\subsection{Chi-Square Analysis of Relationship between Personality Traits and Psychological Biases of Investors}

The relationship between each psychological bias and personality traits was examined for HA hypothesis. Hypotheses made for determining the personality traits of investors and the psychological biases with which they face were tested by chi-square analysis method and the results were given in Table 4.

Table 4. Chi-Square analysis results of the relationship between personality traits and psychological biases

\begin{tabular}{cccccc}
\hline & Extraversion & Agreeableness & Conscientiousness & Neuroticism & $\begin{array}{c}\text { Openess to } \\
\text { Experience }\end{array}$ \\
\hline \multirow{2}{*}{ Representativeness } & $\% 86,6$ & $\% 97,7$ & $\% 96,3$ & $\% 62,0$ & $\% 96,5$ \\
& $\mathrm{P}: 0,013<0,05^{*}$ & $\mathrm{P}: 0,035<0,05^{*}$ & $\mathrm{P}: 0,302$ & $\mathrm{P}: 0,823$ & $\mathrm{P}: 0,158$ \\
\hline \multirow{2}{*}{ Availability } & $\% 85,8$ & $\% 98,9$ & $\% 96,3$ & $\% 62,7$ & $\% 97,4$ \\
& $\mathrm{P}: 0,061$ & $\mathrm{P}: 0,045<0,05^{*}$ & $\mathrm{P}: 0,541$ & $\mathrm{P}: 0,544$ & $\mathrm{P}: 0,430$ \\
\hline \multirow{2}{*}{ Anchoring } & $\% 89,8$ & $\% 97,7$ & $\% 96,7$ & $\% 62,8$ & $\% 94,9$ \\
& $\mathrm{P}: 0,230$ & $\mathrm{P}: 0,047<0,05^{*}$ & $\mathrm{P}: 0,029<0,05^{*}$ & $\mathrm{P}: 0,686$ & $\mathrm{P}: 0,177$ \\
\hline \multirow{2}{*}{ Overconfidence } & $\% 88,6$ & $\% 98,4$ & $\% 97,3$ & $\% 57,8$ & $\% 97,1$ \\
& $\mathrm{P}: 0,003<0,05^{*}$ & $\mathrm{P}: 0,020<0,05^{*}$ & $\mathrm{P}: 0,163$ & $\mathrm{P}: 0,395$ & $\mathrm{P}: 0,004<0,05^{*}$ \\
\hline \multirow{2}{*}{ Overoptimistic } & $\% 92,9$ & $\% 98,2$ & $\% 96,5$ & $\% 55,8$ & $\% 96,9$ \\
& $\mathrm{P}: 0,164$ & $\mathrm{P}: 0,005 \leq 0,05^{*}$ & $\mathrm{P}: 0,842$ & $\mathrm{P}: 0,146$ & $\mathrm{P}: 0,005 \leq 0,05^{*}$ \\
\hline \multirow{2}{*}{ Regret Aversion } & $\% 89,4$ & $\% 97,3$ & $\% 96,3$ & $\% 63,5$ & $\% 96,7$ \\
& $\mathrm{P}: 0,180$ & $\mathrm{P}: 0,210$ & $\mathrm{P}: 0,021<0,05^{*}$ & $\mathrm{P}: 0,036<0,05 *$ & $\mathrm{P}: 0,604$ \\
\hline \multirow{2}{*}{ Herd Effect } & $\% 89,4$ & $\% 98,6$ & $\% 96,5$ & $\% 64,0$ & $\% 96,5$ \\
& $\mathrm{P}: 0,020<0,05^{*}$ & $\mathrm{P}: 0,027<0,05^{*}$ & $\mathrm{P}: 0,812$ & $\mathrm{P}: 0,267$ & $\mathrm{P}: 0,430$ \\
\hline
\end{tabular}

Notes: Pearson Chi-Square test for independence was applied to check the relationship between these variables. The hypothesis formed to check the relationship between personality traits variables and psychological biases is given follow: Hypothesis HA: There is a relationship between personality traits and psychological biases of investors. \% (number) shows that what percentages of personality traits have psychological biases. For example, about $87 \%$ of extravert people have representativeness heuristic. Every personality traits and psychological biases were subjected to chi-square analysis separately. The estimations include Pearson Chi-Square regressors, but are not shown here. The coefficient is significant at the $5 \%$ level.

Extravert people face with psychological biases of representativeness heuristic, overconfidence and herd behavior. Accordingly, it was reached that about $87 \%$ of extravert people have representativeness heuristic. It was seen that about $89 \%$ of extravert people have overconfidence. As a result of the research made by Jamshidinavid, Chavoshani, and Amiri (2012), Bashir et al. (2013a, 2013b), Zaidi and Tauni (2012) it is concluded that extravert investors are in overconfidence bias. It was determined that about $89 \%$ of extravert people have herd behavior. In the research made by Lin (2011), it was reported that extravert people show both herd behavior and overconfidence.

People having agreeableness personality trait face with psychological biases of representativeness heuristic, availability heuristic, anchoring heuristic, overconfidence, over optimism and herd behavior. Accordingly, it was determined that about $98 \%$ of agreeable people have representativeness heuristic, $99 \%$ of the investors have availability heuristic and $98 \%$ of them have anchoring heuristic. It was determined that about $98 \%$ of agreeable people have overconfidence. Different results were obtained in the researches in the literature and Zaidi and Tauni (2012) obtained the result that agreeable people face with the psychological bias of overconfidence. Additionally, it was determined that $98,2 \%$ of agreeable people have over optimism and $98,6 \%$ of the investors have herd behavior. 
People who have conscientiousness personality trait face with the psychological biases of anchoring heuristic and regret aversion. Accordingly, it was determined that about $97 \%$ of people having conscientiousness personality trait have anchoring heuristic. It was also seen that $96 \%$ of conscientious people show regret aversion behavior.

People who have neurotic personality trait face with the psychological bias of regret aversion. It was determined that $63,5 \%$ of people having neurotic personality trait show regret aversion behavior.

People who are open to experience face with the psychological biases of overconfidence and over optimism. It was determined that $97 \%$ of people who have open-to-experience personality trait have overconfidence. Likewise, Sadi et al. (2011) and Lin (2011) determined that there was a positive relationship between openness to experience and overconfidence and $96,6 \%$ of whom have over optimism.

Considering all analysis results, the hypothesis "HA: The relationship between personality traits and psychological biases of investors" is accepted.

\subsection{Logistic Regression Analysis of the Relationship between Personality Traits and Financial Risk Tolerance of} Investors

Dual logistic regression analysis model was used, in order to answer the questions such as "Can we explain the financial risk tolerance (namely; to test the HB hypothesis) by five-factor personality traits?" or "Are the financial risk tolerances of people who are open to experience, extravert, agreeable, conscientious, neurotic high or low?".

The logistic regression analysis (Note 2) results in which this hypothesis was tested are shown in Table 5.

Table 5. Logistic Regression Analysis results of the relationship between five-factor personality traits and financial risk tolerances of investors

\begin{tabular}{|c|c|c|c|c|c|c|c|c|c|c|c|c|c|c|}
\hline & \multirow[b]{2}{*}{ Variables } & \multirow[b]{2}{*}{ 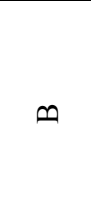 } & \multirow[b]{2}{*}{$\begin{array}{l}\dot{\mu} \\
\dot{n}\end{array}$} & \multirow[b]{2}{*}{$\frac{\sqrt{\pi}}{3}$} & \multirow[b]{2}{*}{ a } & \multirow[b]{2}{*}{ 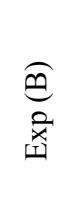 } & \multicolumn{3}{|c|}{ Hos.Lem.T. } & \multicolumn{3}{|c|}{ Omnibus Value } & \multirow{2}{*}{ 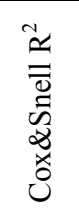 } & \multirow{2}{*}{ 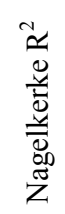 } \\
\hline & & & & & & & $\stackrel{\mathscr{V}}{*}$ & 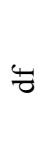 & $\begin{array}{l}\frac{0}{3} \\
\frac{\pi}{7} \\
1 \\
1\end{array}$ & $\mathrm{~K}^{2}$ & $\begin{array}{l}\frac{0}{3} \\
\frac{\pi}{7} \\
1 \\
2\end{array}$ & 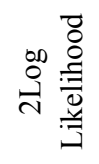 & & \\
\hline A & $\begin{array}{c}\text { Extraversion } \\
\text { Constant } \\
\end{array}$ & $\begin{array}{r}0,25 \\
-0,11 \\
\end{array}$ & $\begin{array}{l}0,13 \\
0,45 \\
\end{array}$ & $\begin{array}{l}3,77 \\
6,16 \\
\end{array}$ & $\begin{array}{c}, 049 * \\
, 013 \\
\end{array}$ & $\begin{array}{c}1,29 \\
, 32 \\
\end{array}$ & 11,1 & 8 & ,19 & 3,82 & 0,05 & 730,0 & 0,67 & 0,71 \\
\hline $\mathrm{B}$ & $\begin{array}{c}\text { Agreeableness } \\
\text { Constant } \\
\end{array}$ & $\begin{array}{c}-0,12 \\
0,18 \\
\end{array}$ & $\begin{array}{l}0,16 \\
0,62 \\
\end{array}$ & $\begin{array}{l}, 51 \\
, 08 \\
\end{array}$ & $\begin{array}{l}, 047^{*} \\
, 769 \\
\end{array}$ & $\begin{array}{c}, 88 \\
1,20 \\
\end{array}$ & 10,3 & 8 &, 24 & 0,51 & 0,04 & 733,3 & 0,46 & 0,51 \\
\hline $\mathrm{C}$ & $\begin{array}{c}\text { Conscientiousness } \\
\text { Constant } \\
\end{array}$ & $\begin{array}{c}-0,13 \\
0,25\end{array}$ & $\begin{array}{l}0,13 \\
0,51 \\
\end{array}$ & $\begin{array}{l}1,03 \\
, 24 \\
\end{array}$ & $\begin{array}{l}, 031^{*} \\
, 624\end{array}$ & $\begin{array}{c}, 87 \\
1,28 \\
\end{array}$ & 2,8 & 8 & ,94 & 1,03 & 0,03 & 732,8 & 0,36 & 0,38 \\
\hline $\mathrm{D}$ & $\begin{array}{c}\text { Neuroticism } \\
\text { Constant }\end{array}$ & $\begin{array}{l}0,22 \\
0,35\end{array}$ & $\begin{array}{l}0,13 \\
0,37 \\
\end{array}$ & $\begin{array}{c}2,85 \\
, 89 \\
\end{array}$ & $\begin{array}{c}, 020^{*} \\
, 345\end{array}$ & $\begin{array}{c}, 80 \\
1,42 \\
\end{array}$ & 11,0 & 8 & ,19 & 2,87 & 0,02 & 731,0 & 0,65 & 0,71 \\
\hline $\mathrm{E}$ & $\begin{array}{l}\text { Openess to Exp. } \\
\text { Constant }\end{array}$ & $\begin{array}{c}0,20 \\
-1,03\end{array}$ & $\begin{array}{l}0,15 \\
0,57\end{array}$ & $\begin{array}{l}1,86 \\
3,25\end{array}$ & $\begin{array}{c}, 017^{*} \\
, 071\end{array}$ & $\begin{array}{l}1,22 \\
, 35\end{array}$ & 4,2 & 8 & ,83 & 1,87 & 0,01 & 732,0 & 0,34 & 0,46 \\
\hline
\end{tabular}

Notes: This table shows the coefficients estimated by the logistic regression model described by HB hypothesis. The models used are as follows;

$\operatorname{Pr}($ Financial Risk Tolerances, hig $=1$; low: 0$)=\beta \mathrm{o}+\beta 1$ Extraversion it, $+\varepsilon i t$

$\operatorname{Pr}($ Financial Risk Tolerances, hig $=1$; low: 0$)=\beta \mathrm{o}+\beta 1$ Agreeableness it, $+\varepsilon i t$

$\operatorname{Pr}($ Financial Risk Tolerances, hig $=1$; low: 0$)=\beta \mathrm{o}+\beta 1$ Conscientiousness it, $+\varepsilon i t$

$\operatorname{Pr}($ Financial Risk Tolerances, hig $=1 ;$ low: 0$)=\beta \mathrm{o}+\beta 1$ Neuroticism it, $+\varepsilon i$ it

$\operatorname{Pr}($ Financial Risk Tolerances, hig $=1$; low: 0$)=\beta 0+\beta 1$ Openess to Exp. it, $+\varepsilon i t$

Logistic regression is a regression model where the dependent variable is categorical. That is, a financial risk tolerance is a categorical variable. If financial risk tolerance is high, categorical variable would get a value of 1 not a value 0 . Personality Traits are independent variables. Hos.Lem.T.: The Hosmer-Lemeshow test is a statistical test for goodness of fit for logistic regression models. Cox \& Snell R2 and Nagelkerke $\mathrm{R}^{2}$ refer to the degree of the relationship between independent variables with the dependent variable. This values for all models are good. The coefficient is significant at the $5 \%$ level.

Table 5 Panel A shows the logistic regression analysis results of the relationship between dependent variable financial risk tolerance and independent variable extravert personality trait. According to Wald criteria, it was 
determined that extravert personality trait is significant for predicting the financial risk tolerance (p: $0,049<0,05)$. According to the the findings, it is seen that extravert personality trait explains the financial risk tolerance and extravert people have high financial risk tolerance.

As seen in Table 5 Panel B, as agreeable personality trait is p: $0,047<0,05$ in predicting the financial risk tolerance, it is statistically accepted as significant. This result explains the financial risk tolerance of agreeableness personality trait, but shows that agreeable people have low financial risk tolerances.

Panel $\mathrm{C}$ shows the logistic regression analysis results of the relationship between independent variable conscientious personality trait and dependent variable financial risk tolerance. According to Wald criteria, conscientious personality variable is accepted significant in predicting the financial risk tolerance ( $\mathrm{p}: 0,031<0,05)$. It is seen that this explains the financial risk tolerance of conscientious personality trait and conscientious people have low financial risk tolerance.

Panel D shows the logistic regression analysis results of the relationship between independent variable neurotic personality trait and dependent variable financial risk tolerance. Accordingly, there is a relationship between neurotic personality trait and financial risk tolerance $(\mathrm{p}: 0,031<0,05)$. Thus, neurotic people have high financial risk tolerances. As seen in Panel E, it is accepted as significant (p: $0,17<0,05)$ according to the logistic regression analysis results of the relationship between openness-to-experience personality trait and financial risk tolerance. As a result, there is a statistically significant relationship between openness to experience and financial risk tolerance. People who are open to experience have high financial risk tolerance.

Considering all findings, the hypothesis "HB: There is a relationship between personality traits and financial risk tolerances of investors." is accepted. In the literature, it was determined that similar results were obtained. Accordingly, Dohmen et al. (2007) found in their research that people who are extravert and open to experience are willing to take risk. Durand, Newby, and Sanghani (2006) determined that people who are neurotic, open to experience and agreeable take high risk and people who are conscientious take low risk. Risk attitudes of only agreeable people do not correspond to this study. Peterson (2012) argues that neurotic people take more risk in order to take back their losses and conscientious people do not take risk when they make loss.

\section{Conclusion}

It is known that each individual has different personality traits. Likewise, it is possible that each individual faces with psychological biases. Moreover, each individual faces with different psychological biases to the different degree. As suggested by behavioral finance, risk attitudes of individuals have multiple dimensions as well as their personality traits and psychological biases. Investment risk perception types of individuals continually vary depending on their attitudes against risk. Instead of determining only one investment strategy for each investor by evaluating them as "risk averse" in financial markets, it is required to determine investment strategies according to personality traits, financial risk tolerances of each investor.

The fact that investors are aware of psychological biases with which they can face by knowing their own personality traits and also make decisions depending on their financial risk tolerance can provide an important advantage in financial markets where there is a fierce competition. Thus, those differences were presented and classified in this research. According to the research findings, it is seen that each personality faces with different biases and each investor has different risk tolerances. In this case, the most important factor is the knowledge of investors on their own personality and psychological biases. In other words, this is how they know themselves, because a personality that an individual have and a personality that he wants to be can vary. On the other hand, investors may not know the reason why mistakes or failures arise from or the opinion which cause those mistakes or failures.

Briefly, hypotheses were divided into two groups and separate analysis were made for each hypothesis in this research made with the purpose of examining the relationship among personality traits, psychological biases and financial risk tolerances of investors. The relationship between personality traits and psychological biases was tested by "chi-square analysis" and the relationship between five-factor personality traits and financial risk tolerance was tested by "logistic regression analysis".

According to the research findings, it was determined that there was a relationship between personality traits and psychological biases of investors and the personality traits of investors affected their financial risk tolerances. Investors included in the research have low financial risk tolerances and those investors are prone to representativeness heuristic most. It was determined that they showed agreeableness personality trait more and those who faced with psychological biases most were agreeable people and those who faced with psychological biases least were neurotic people.

Additionally, five-factor personality model was used for classifying the personality traits in this research. Different approaches may be obtained by making personality classification measurements by other models such as Myers Briggs Personality Model, A and B type personality model. When examining the relationship between personality 
traits and financial risk tolerance, the relationship between psychological biases and financial risk tolerance and the relationship between psychological biases and demographic traits were not tested in this research. The studies carried out about behavioral finance focus on the relationship between these variables and those factors can be included in researches for the following studies.

\section{Acknowledgements}

This paper has been produced doctoral thesis that name is "Investor Bias in Terms of Investment Psychology, Financial Risk Tolerance and Financial Personality: A Field Survey on Individual Inverstor"

(Muğla Sitkı Koçman University, Institute of Social Sciences, 2015).

This study is supported by Muğla Sıtkı Koçman University Scientific Research Project Office.

\section{References}

Ali, I., \& Waheed, M. S. (2013). Determinants of Small Equity Investor's Risk Assumption Attitude. Paper presented at the anual meeting fort he Society of 2nd. -International Conference on Humanities, London, June 17-18.

Bailard, E. T., David, L. B., \& Ronald, W. K. (1986). Personal Money Management (5th ed.). Chicago: Prentice Hall College.

Bashir, T., Nazish, A., Arslan, A. B., Aaqiba, J., \& Ayesha, T. (2013b). Are Behavioral Biases Influenced By Demographic Characteristic \& Personality Traits? Evidence From Pakistan. European Scientific Journal, 9(29), 277-293.

Bashir, T., Safia, F., Irum, S., Wagas, A., \& Ghullam, J. (2013a). Impact of Demographics and Personality Traits on Confidence Level: Determinants of Overconfidence: Evidence from Employees and Students. Journal of Business and Management, 10, 58-67.

Black, F., Michael, C. J., \& Myron, S. (1972). The Capital Asset Pricing Model: Some Empirical Tests. In Michael C. Jensen (Ed.), Studies in the Theory of Capital Markets. New York: Praeger Publishers.

Borghans, L., Angela, L. D., James, J. H., \& Baster, W. (2008). The Economics and Psychology of Personality Traits, Discussion Paper No: 3333. Forschungsinstitut zur Zukunft der Arbeit Institute for the Study of Labor. Retrieved February 10, 2015, from http://dx.doi.org/10.3386/w13810

Brozynski, T., Lukas, M., \& Ulrich, S. (2004). The Impact of Experience on Risk Taking, Overconfidence and Herding of Fund Managers: Complementary Survey Evidence. Discussion Paper No: 292. University of Hannover School of Economics and Management. Retrieved June 4, 2015, from http://diskussionspapiere.wiwi.uni-hannover.de/pdf_bib/dp-292.pdf

Bruni, L., \& Robert, S. (2007). The Road not Taken: How Psychology was Removed From Economics, and How It Might be Brought Back. The Economic Journal, 117(516), 146-173. http://dx.doi.org/10.1111/j.1468-0297.2007.02005.x

Camerer, C. F. (1995). Individual Decision Making. In J. H. Kagel and A. E. Roth (Eds.), Handbook of Experimental Economics (pp. 587-703). Princeton: Princeton University Press.

Camerer, C. F. (1997). Rules for Experimenting in Psychology and Economics, and Why They Differ. In W. Albers et al. (Eds.), Experimental Understanding Studies of Strategic Interaction: Essays in Honor of Reinhard Selten (pp. 313-327). Berlin: Springer-Verlag Heidelberg. http://dx.doi.org/10.1007/978-3-642-60495-9_25

Cronbach, L. J. (1951). Coefficient Alpha and The Internal Structure of Tests. Psychometrika, 16(3), 297-334. http://dx.doi.org/10.1007/BF02310555

Dobelli, R. (2014). The Art of Thinking Clearly. USA: Harper Paperbacks.

Dohmen, T., Armin, F., David, H., \& Uwe, S. (2007). Are Risk Aversion and Impatience Related to Cognitive Ability?. Discussion Paper, No: 2735. Forschungsinstitut zur Zukunft der Arbeit Institute for the Study of Labor, Retrieved May 16, 2015, from http://ftp.iza.org/dp2735.pdf

Dowling, M., \& Brian, L. (2010). Other Behavioral Biases. In H. Kent Baker and John R. Nofsinger (Eds.), Behavioral Finance: Investors, Corporations and Markets (pp. 313-331). The Robert Kolb Series in Finance. Canada: John Wiley \& Sons, Inc. http://dx.doi.org/10.1002/9781118258415.ch17

Durand, R. B., Rick, N., \& Jay, S. (2008). An Intimate Portrait of the Individual Investor. The Journal of Behavioral Finance, 9(4), 193-208. http://dx.doi.org/10.1080/15427560802341020

Eaton, R., \& Douglas, V. (2000). The Psychology Behind Common Investor Mistakes. Market Structure, The AAII Journal, $1-5$. 
Fama, E. (1970). Efficient Capital Markets: A Review of Theory and Empirical Work. Journal of Finance, 25(2), 383-417. http://dx.doi.org/10.2307/2325486

Goldberg, L. R. (1971). A Historical Survey of Personality Scales and Inventories. In Paul McReynolds (Ed.), Advances in Psychological Assessment (Vol. II, pp. 293-336). USA: Science and Behavior Books Inc.

Goldstein, E. B. (2013). Cognitive Psychology: Connecting Mind, Research and Everyday Experience. USA: Wadsworth Publishing.

Grable, J. E., \& R. H. L. (1998). Investor Risk Tolerance: Testing The Efficacy of Demographics As Differentiating and Classifying Factors. Financial Counseling and Planning, 9, 61-74.

Hallahan, T. A., Robert, W. F., \& Michael, D. M. (2004). An Emprical Investigation of Personal Financial Risk Tolerance. Financial Services Review, 13, 57-58.

Jamshidinavid, B., Mojtaba, C., \& Shahla, A. (2012). The Impact of Demographic and Psychological Characteristics on The Investment Prejudices in Tehran Stock. European Journal of Business and Social Sciences, 1(5), 41-53.

John, O. P., Donahue, E. M., \& Kentle, R. L. (1991). The Big Five Inventory--Versions 4a and 54. Berkeley, CA: University of California, Berkeley, Institute of Personality and Social Research.

Jureviciene, D., \& Kristina, J. (2012). The Impact of Individuals' Financial Behaviour on Investment Decisions. Paper presented at the anual meeting fort he Society of 1 st. Electronic International Interdisciplinary Conference, Slovakia, September 3-7.

Kahneman, D., \& Tversky, A. (1979). Prospect Theory: An Analysis of Decision Under Risk. Econometrica, 47(2), 263-291. http://dx.doi.org/10.2307/1914185

Kleinman, P. (2014). Psych 101: Adams 101: Psychology Facts, Basics, Statistics, Tests, and More! USA: Adams Media, a division of $\mathrm{F}+\mathrm{W}$ Media Inc.

Kojabad, N. A. (2012). Impacts of behavioural finance on investor decisions in stock exchange markets: The comparison between the model of Tehran stock Exchange and Istanbul Stock Exchange. PhD diss. University of Ege.

Kowert, P., \& Margaret, G. H. (2013). Who Takes Risks? Daring and Caution in Foreign Policy Making. The Journal of Conflict Resolution, 41, 611-637. http://dx.doi.org/10.1177/0022002797041005001

Lagnado, D. A., \& Steven, A. S. (2004). Inside and Outside Probability Judgement. In Derek J. Koehler and Nigel Harvey (Eds.), Blackwell Handbook of Judgement and Decision Making (pp. 157-177). Handbooks of Experimental Psychology. UK: Wiley-Blackwell Publishing Ltd.

Laibson, D., \& Richard, Z. (1998). Amos Tversky and the Ascent of Behavioral Economics. Journal of Risk and Uncertainty, 16(1), 7-47. http://dx.doi.org/10.1023/A:1007717224343

Lakshmi, P., Visalakshmi, S., Thamaraiselvan, N., \& Senthilarasu, B. (2013). Assessing The Linkage of Behavioral Traits and Investment Decisions Using SEM Approach. Journal of Economics and Management, 7(2), $221-241$.

Lehrer, J. (2009). How We Decide. USA: Hougton Mifflin Harcourt Publishing Company.

Lin, H. (2011). Elucidating The Influence of Demographics and Psychological Traits on Investment Biases. World Academy of Science, Engineering and Technology, 5(5), 137-142.

Lin, H. (2012). How Herding Bias Could Be Derived From Individual Investor Types and Risk Tolerance?. World Academy of Science, Engineering and Technology, 6(6), 767-772.

Loewenstein, G. (1999). Experimental Economics from The Viewpoint of Behavioural Economics. The Economic Journal, 109(453), 25-34. http://dx.doi.org/10.1111/1468-0297.00400

Markowitz, H. M. (1952). Portfolio Selection. The Journal of Finance, 7(1), 77-91. http://dx.doi.org/10.2307/2975974

McCrae, R. R. (2009). The Five-Factor Model of Personality Traits: Consensus and Controversy. In Philip J. Corr and Gerald Matthews (Eds.), The Cambridge Handbook of Personality Psychology (pp. 148-162). Cambridge: Cambridge University Press. http://dx.doi.org/10.1017/CBO9780511596544.012

McGuckian, F. (2013). Behavioral Finance and Financial Markets: Micro, Macro, and Corporate. PhD diss. University of Politecnica delle Marche.

Murgea, A. (2010). Classical and Behavioural Finance in Investor Decision. Annals of University of Craiova Economic Sciences Series, 2(38), 212-223. 
Nofsinger, J. R., \& Richard, W. S. (1999). Herding and Feedback Trading by Institutional and Individual Investors. The Journal of Finance, 54(6), 2263-2295. http://dx.doi.org/10.1111/0022-1082.00188

Nunnally, J. C., \& Bernstein, I. H. (1994). Psychometric Theory (3rd ed.). New York: McGraw-Hill.

Parker, T. (2014, November). Behavioral Bias - Cognitive Vs. Emotional Bias in Investing. Investopedia, 2015.

Peterson, R. L. (2012). Inside the Investor's Brain: The Power of Mind Over Money. USA: John Wiley \& Sons, Inc. http://dx.doi.org/10.1002/9781119196945

Pompian, M. M. (2008). Using Behavioral Investor Types to Build Better Relationships with Your Clients. Journal of Financial Planning, 21(10), 64-76.

Prabhakaran, K., \& Karthika, P. (2011). A Study on Risk Perception and Portfolio Management of Equity Investors in Coimbatore City. Journal of Management and Science, 1(2), 1-13.

Roszkowski, M. J., \& Geoff, D. (2010). Risk Perception and Risk Tolerance Changes Attributable to The 2008 Economic Crisis: A Subtle but Critical Difference. Journal of Financial Service Professionals, 64(4), 42-53.

Sadi, R., Hassan, G., Mohammad, R., \& Aryan, G. (2011). Behavioral Finance: The Explanation of Investors' Personality and Perceptual Biases Effects on Financial Decisions. International Journal of Economics and Finance, 3(5), 234-241. http://dx.doi.org/10.5539/ijef.v3n5p234

Shalini, K. S., Ashok, P. A., \& Nand, D. (2013). An Exploratory Inquiry into the Psychological Biases in Financial Investment Behavior. Journal of Behavioral Finance, 14(2), 94-103. http://dx.doi.org/10.1080/15427560.2013.790387

Siddiqui, S., \& ve Shuchita, S. (2009). Behaviour Influence on Stock Market Investments: a surve. The Journal of Management Awareness, 12(2), 95-104.

Sutherland, S. (2011). Irrationality: The Enemy Within. London: Pinter \& Martin Ltd

Thomas, T. C., \& Rajendran, G. (2012). BB\&K Five-way Model and Investment Behavior of Individual Investors: Evidence From India. Journal of Economics and Management, 6(1), 115-127.

Venter, G. V. de, David, M., \& Geoff, D. (2007). A Longitudinal Study of Financial Risk Tolerance. Journal of Economic Psychology, 33(4), 794-800. http://dx.doi.org/10.1016/j.joep.2012.03.001

Vikash, R., Yilang, Z., Imad, M., \& Michael, G. (2014). A Behavioural Finance Approach to Working Capital Management. The European Journal of Finance. http://dx.doi.org/10.1080/1351847X.2014.883549

Walker, S. H., \& Duncan, D. B. (1967). Estimation of the Probability of An Event as a Function of Several Independent Variables. Biometrika, 54, 167-178. http://dx.doi.org/10.2307/2333860

Warren, B. (2012). Behavioral Finance and Me, or How I Came to See The Light. The European Journal of Finance. http://dx.doi.org/10.1080/1351847X.2012.712922

Wolfgang, B., Michael, R., \& Astrid, J. S. (2014). Risk Aversion Vs. Individualism: What Drives Risk Taking in Household Finance? The European Journal of Finance, 20(5), 446-462. http://dx.doi.org/10.1080/1351847X.2012.714792

Zaidi, F. B., \& Muhammed, Z. T. (2012). Influence of Investor's Personality Traits and Demographics on Overconfidence Bias. Interdisciplinary Journal of Contemporary Research in Business, 4(6), 730-746.

Zweig, J. (2011). Your Money and Your Brain. USA: Souvenir Press Ltd.

\section{Notes}

Note 1. Cronbach's alpha is a measure of internal consistency, that is to say, how closely related a set of items are as a group. It is considered to be a measure of scale reliability. Cronbach's alpha is a function of the number of items in a test, the average covariance between item-pairs, and the variance of the total score.Technically, Cronbach's alpha is not a statistical test - it is a coefficient of reliability or consistency (Cronbach 1951).

Note 2. Logistic regression was developed by statistician David Cox in 1958. As such it is not a classification method. It could be called a qualitative response/discrete choice model in the terminology of economics. Logistic regression, also called a logit model, is used to model dichotomous outcome variables. In the logit model the log odds of the outcome is modeled as a linear combination of the predictor variables. Logistic regression measures the relationship between the categorical dependent variable and one or more independent variables by estimating probabilities using a logistic function, which is the cumulative logistic distribution (Walker and Duncan 1967). 